\title{
Can Immunopathology Explain Why Metastasizing Lung Cancer Cells Manifest Ubiquity in the Blood Stream but Selectivity in Lymph Node Colonization?
}

\section{Wilson IB Onuigbo*}

Department of Pathology, Medical Foundation and Clinic, Enugu 40001, Nigeria

\begin{abstract}
It has been calculated that metastasizing lung cancers are numbered in millions. It has also been argued that lymph nodes occupy the status of organs in cancer metastasis. Accordingly, both the tissues now generally regarded as organs as well as lymph nodes, which are of that same status, should all be haphazardly showered by circulating cancer cells. On the contrary, these two sets of organs exhibit very conspicuous diversity in their colonization patterns. Thus, the better known organs generally exhibit scattered secondaries all over the body while the lymph nodes are selectively affected. Thus, in the words of Willis, a foremost cancer authority, lung cancers "often" exhibit discrete deposits in the abdominal lymph nodes, "these diminishing in centrifugal order." Indeed, such an order is not known as regards, say, the liver, adrenal gland, kidney and ovaries. Therefore, is Nature showing signals which ought to be decoded? Here, I argue that this is possible. Moreover, the welcome expectation is that such a study of lung cancer can usher in an immunological breakthrough which may point to target therapy and thereby conduce to cancer cure.
\end{abstract}

Keywords: Cancer; Metastasis; Lymph nodes; Necrosis

\section{Introduction}

On account of its position in the human body, lung cancer is without parallel in colonization capability $[1,2]$. Moreover, the numbers thrown into the circulation are of the order of millions [3]. Surely, these must reach all tissues indiscriminately. And, yet, there are discernible pattern formations in the lymph node system.

\section{Lymph node patterns}

Over the years, I have provided some results in this ravaging realm of oncology. This was thanks to the great goodwill of the late Professor Cappell, who reported my earliest work in glowing terms [4]. Little wonder that my grooming ground was the University Department of Pathology at the Glasgow Western Infirmary, an Institution described in the Bulletin of the History of Medicine [5] as being second to none in Britain. There, I introduced, instead of the usual casual display of bodily parts on the Table, the Mono-Block Formalin-Fixation Method [6] (Figure 1). The accruing developments are worthy of chronological classification as follows:

a. 1961. Centrifugal metastasis occurs, the proximal lymph nodes being earlier and more grossly involved [7].

b. 1962. Contralateral metastasis may occur in the neck, the line of cross-over to the other side being apparent [8].

c. 1962. Triple carcinomata in one lung were reported. The squamous celled growth spread to a contiguous node and another near paraesophageal node. The polygonal-cell carcinoma showed two neighboring invaded nodes. The adenocarcinoma, unlike the others, spread over considerable areas, involving no less than 72 lymph nodes, the growths occurring bilaterally but asymmetrically [9].

d. 1963. The situation of the earliest deposits within the retrogradely situated abdominal nodes revealed, as shown in 6 statements, that this was in the convex border, where incoming lymph vessels arrive and not in the concave border, where outgoing lymph vessels emerge [10]. This was necessarily interpreted in terms of the formation of new lymph vessels. This phenomenon is nowadays called "lymphangiogenesis" whose review I have provided elsewhere [11].

e. 1964. A general consideration of lymph node metastases in lung cancer was vicariously undertaken. This led to the delineation of what I called "natural laws" as follows [12]:

- Ipsilateral nodes are invaded more grossly than contralateral ones.

- Contiguous nodes are invaded more grossly than distant nodes.

- Contiguous nodes are invaded in a more orderly fashion than distant nodes.

- Particular nodes are invaded while others may be skipped.

- Early metastases are truly discrete while subsequent dispersal may through coalescence simulate direct extension.

Therefore, I concluded with a last phrase, namely, the need "to chart virgin fields of knowledge."

\section{Discussion}

In sum, from ancient times, lymph nodes were believed to be "suitable soils" for cancer colonization [13]. Lo and behold! Because of the wholesale nourishing function of the blood supply, its contained cancer cells must be reaching all the lymph nodes. Nevertheless comparable colonization does not materialize. Instead, there is an

*Corresponding author: Wilson I. B. Onuigbo, Department of Pathology Medical Foundation and Clinic, 8 Nsukka Lane, Enugu 40001, Nigeria, Tel: +2348037208680; E-mail: wilson.onuigbo@gmail.com

Received November 09, 2015; Accepted November 24, 2015; Published November 27, 2015

Citation: Wilson IB (2015) Can Immunopathology Explain Why Metastasizing Lung Cancer Cells Manifest Ubiquity in the Blood Stream but Selectivity in Lymph Node Colonization?. Immunochem Immunopathol 1: 110. doi:10.4172/24699756.1000110

Copyright: (C) 2015 Wilson IB. This is an open-access article distributed under the terms of the Creative Commons Attribution License, which permits unrestricted use, distribution, and reproduction in any medium, provided the original author and source are credited. 


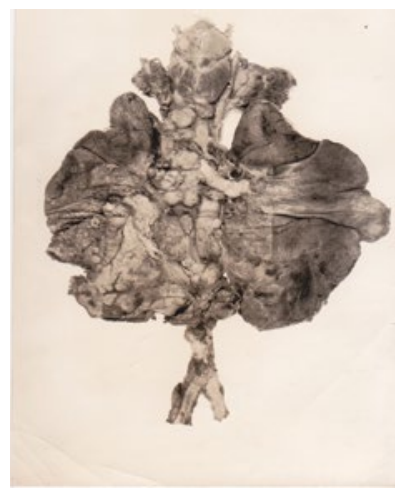

Figure 1: Early stage of axial preservation showing the as yet to be removed lungs. Note the aortic bifurcation and the lymph nodes nearby

orderly pattern of spread whose topography is not that of blood spread but of lymph spread. Incidentally, in an embryonic paper on lung cancer [14], I had the temerity to recommend that research should be carried out in order to elucidate "a possible difference in immunological potentiality between blood and lymph."

Today, the giant status of immunology is of great concern here as regards cancer, especially lung cancer. It seems to me that immunology should be geared specifically towards decoding the secrets of Nature in lung cancer. In other words, the chequered existence of the bloodborne lung cancer cell requires penetrating and purposive decoding researches $[15,16]$.

Concerning such researches, the importance of the microenvironment is increasingly being realized $[17,18]$. However, we should go back to 1798 when Sir Astley Cooper, through animal experimentation and necropsy investigation, emphasized that red cells occur in the thoracic duct which is important to the "human economy" [19]. Concerning its duty, my experience revealed the most important evidence of accompanying necrosis itself. As I concluded pertinently, "Necrosis of the cancer cells was apparent in 3 cases, but it was clear that this had occurred in association with large aggregates of the malignant cells and that among such aggregated cells red blood corpuscles abounded." [20].

It is to be noted that this form of necrosis is associated with the phenomenon of metastasis itself, unlike the Necrosis which occurs in situ within the primary tumor itself. The latter has long been attributed to "Tumor Necrosis Factor" [21] which has been as defined thus: "Tumor necrosis was defined when there were necrotic tissues in the tumor mass at low magnification." [22]. The great point is that the thoracic duct necrosis is part and parcel of the metastasis formation, i.e., not merely of tumor formation. This is important because the ductal cancer cells had begun the active process of metastasis by first detaching ably from the primary focus and secondly transporting themselves during the next phase!

On this account, I have named the thoracic duct Factor as the "Erythrocyte Associated Necrosis Factor" (EANF) [23]. This Factor is reminiscent of when, long ago, bleeding was a great problem. Thereafter, the Coagulation Factor was discovered and its treatment became assured [24]. It is, therefore, my hypothesis that, if EANF is discovered, the omens will be good!

\section{Future Prospects}

Now, developments have attained to such a height that there are (i) the old cannulation undertaken simply in the thoracic duct [25], and (ii) the new technique of intravital videomicroscopy [26]. Therefore, since the killer lung cancers superbaound [27], the patients, who give their consent as legally required [28], should be cannulated in order to retrieve the two necessary subsets required in scientific investigation, namely, the living individual cancer cells and the dying massed cancer cells commingled with red corpuscles. In this way, the newly founded, blossoming, well-funded translational laboratories should swing into action [29]. The future owes them the duty to replicate EANF [30].

Incidentally, EANF is likely to be molecular. Indeed, as I like to see it, immunology can and should be guided towards decoding the signals which Nature herself has been sending out in the bodies of patients dying with lung cancer. Elsewhere, I noted that the medical masters of yester years believed that Nature's own ways need to be not only identified but also exploited [31]. Hitherto, I had made this appeal in journals such as Single Cell Biology [32] and International Journal of Surgery [33]. Accordingly, let this Journal, Immunochemistry and Immunopathology, lend a helping hand. Thus, as Jubb's associates reminded all, "The rapid pace of drug discovery and drug development in oncology, immunology and ophthalmology brings new challenges" [34]. Therefore, it is to be hoped that breakthroughs will, sooner than later, emerge and point in the direction of that target therapy which can conduce to cancer cure.

In this context, as I showed historically [35], a major problem has long been the perplexing tissue-specific pattern of metastatic progression in cancer which has been weighed on the scale of "seed" and "soil." With this in mind, Kaplan's group [36] looked into several questions, including genetic regulation and activation of specific chemokines/cytokines and proteases, loss of deletion allows for acquisition of unique and specific properties that connect tumor cells with the metastatic microenvironment. Be that as it may, I am persuaded that the thoracic duct has provided a readily accessible microenvironment for translational research on EANF [32]. Indeed, a fruitful future is to be expected in immunopathology with special reference to the thoracic duct.

\section{References}

1. Daniels M, Goh F, Wright CM, Sriram KB, Relan V, et al. (2012) Whole genome sequencing for lung cancer. J Thorac Dis 4: 155-163.

2. Spiro SG, Gould MK, Colice GL (2007) Initial evaluation of the patient with lung cancer: symptoms, signs, laboratory tests, and paraneoplastic syndromes: ACCP evidenced-based clinical practice guidelines. 2nd edn. Chest 132 149S-160S

3. Peck K, Sher YP, Shih JY, Roffler SR, Wu CW, et al. (1998) Detection and quantitation of circulating cancer cells in the peripheral blood of lung cancer patients. Cancer Res 58: 2761-2765.

4. Robert Muir, Daniel FC (1958) Muir's Text-Book of Pathology. 7th edn. London: Arnoled. p. 505.

5. Jacyna LS (1988) The laboratory and the clinic: the impact of pathology on surgical diagnosis in the Glasgow Western Infirmary, 1875-1910. Bull Hist Med 62: 384-406.

6. Onuigbo WIB (1963) A mono-block formalin-fixation method for investigating cancer metastasis. Z Krebsforsch 65: 209-210.

7. Onuigbo WIB (1961) Centrifugal metastasis in lung cancer. Br J Dis Chest 55 86-90.

8. Onuigbo WIB (1962) Contralateral cervical node metastases in lung cancer Thorax 17: 201-204.

9. Onuigbo WIB (1962) Multiple carcinomata of the lung (a case with three primary tumours). Br J Dis Chest 56: 144-146.

10. Onuigbo WIB (1963) A modified theory of retrograde lymphatic metastasis in lung cancer. Br J Dis Chest 57: 120-125. 
Citation: Wilson IB (2015) Can Immunopathology Explain Why Metastasizing Lung Cancer Cells Manifest Ubiquity in the Blood Stream but Selectivity in Lymph Node Colonization?. Immunochem Immunopathol 1: 110. doi:10.4172/2469-9756.1000110

Page 3 of 3

11. Onuigbo WIB (2014) Lymphangiogenesis in cancer: A Review. Biochem Physiol 3: 138

12. Onuigbo WIB (1964) Lymph node metastases in lung cancer. Geriatrics 19 380-388.

13. Onuigbo WIB (1975) Origins of the soil theory of cancer metastasis. Mater Med Pol 7: 254-255.

14. Onuigbo WIB (1957) Some observations on the spread of lung cancer in the body. Br J Cancer 11: 175-180.

15. Onuigbo WIB (1974) The spread of lung cancer to the heart, pericardium and great vessels. Jpn Heart J 15: 234-238.

16. Onuigbo WIB (2000) Ten anomalous patterns of lung cancer spread with a single explanatory hypothesis. Med Hypotheses 55: 227-231.

17. Joyce JA, Pollard JW (2009) Microenvironmental regulation of metastasis. Nat Rev Cancer 9: 239-252.

18. Fidler IJ, Kim SJ, Langley RR (2007) The role of the organ microenvironment in the biology and therapy of cancer metastasis. J Cell Biochem 101: 927-936.

19. Cooper A, Babington W, Haighton J, Smith R, Cheston RB (1798) Medica records and researches. Harvard University, London, T. Cox.

20. Onuigbo WIB (1967) The carriage of cancer cells by the thoracic duct. $\mathrm{Br} J$ Cancer 21: 496-500.

21. Sidhu RS, Bollon AP (1993) Tumor necrosis factor activities and cancer therapy--a perspective. Pharmacol Ther 57: 79-128.

22. Park SY, Lee HS, Jang HJ, Lee GK, Chung KY, et al. (2011) Tumor necrosis as a prognostic factor for stage IA non-small cell lung cancer. Ann Thorac Surg 91: 1668-1673.

23. Onuigbo WIB (2013) Nature's necrosis factor when associated with erythrocytes may not only explain the surprises in lung cancer metastases but also suggest target therapy. Med Hypotheses 80: 698-700.
24. Laurence DR, Bennette PN (1987) Clinical Pharmacology. 6th edn. ELBS Churchill. Livingstone 567-570.

25. Mittleider D, Dykes TA, Cicuto KP, Amberson SM, Leusner CR (2008) Retrograde cannulation of the thoracic duct and embolization of the cisterna chyli in the treatment of chylous ascites. J Vasc Interv Radiol 19: 285-290.

26. Chambers AF, MacDonald IC, Schmidt EE, Koop S, Morris VL, et al. (1995) Steps in tumor metastasis: new concepts from intravital videomicroscopy. Cancer Metastasis Rev 14: 279-301.

27. Zhan $P$, Song $Y$ (2012) Status quo and prospects of the translational research on lung cancer in China. Transl Lung Cancer Res 1: 91-93.

28. Onuigbo WIB (2014) Historical Origins of Informed Consent in Cancer Surgery Forensic Res 5: 246-247.

29. Woolf SH (2008) The meaning of translational research and why it matters. JAMA 299: 211-213.

30. Onuigbo WIB (2014) Is there a natural translational system suitable for the target therapy of lung cancer? Trans Med 4: 130

31. Onuigbo WIB (2015) The visionary views of medical masters of yester years on Nature's norms point to present prospects in the target therapy of cancer. Biol Med 7: 221.

32. Onuigbo WIB (2014) The scientific significance of the role of the thoracic duct in cancer cell carriage: A review. Single Cell Biol 3: 104.

33. Onuigbo WIB (2014) Anomalous lung cancer cell carriage: a historical review with present prospects. Int J Surg 12: 734-736.

34. Jubb AM, Koeppen H, Reis-Filho JS (2014) Pathology in drug discovery and development. J Pathol 232: 99-102.

35. Onuigbo WIB (1963) A history of the cell theory of cancer metastasis. Gesnerus 20: $90-95$

36. Kaplan RN, Rafii S, Lyden D (2006) Preparing the "soil": the premetastatic niche. Cancer Res 66: 11089-11093. 